\title{
The Genetic Diversity of Rickettsiella Symbionts in Ixodes ricinus Throughout Europe
}

\author{
Aitor Garcia-Vozmediano ${ }^{1}$ (1) - Laura Tomassone ${ }^{1}$ (1) $\cdot$ Manoj Fonville $^{2} \cdot$ Luigi Bertolotti $^{1}$ (1) $\cdot$ Dieter Heylen $^{3,4,5}$. \\ Nannet D. Fabri ${ }^{6,7}$. Jolyon M. Medlock ${ }^{8} \cdot$ Ard M. Nijhof $^{9}{ }^{\circledR} \cdot$ Kayleigh M. Hansford $^{8} \cdot$ Hein Sprong $^{2}{ }^{\circledR}$. \\ Aleksandra I. Krawczyk ${ }^{2,10} \mathbb{B}$
}

Received: 12 May 2021 / Accepted: 10 September 2021 / Published online: 28 September 2021

(c) The Author(s) 2021

\begin{abstract}
Rickettsiella species are bacterial symbionts that are present in a great variety of arthropod species, including ixodid ticks. However, little is known about their genetic diversity and distribution in Ixodes ricinus, as well as their relationship with other tick-associated bacteria. In this study, we investigated the occurrence and the genetic diversity of Rickettsiella spp. in I. ricinus throughout Europe and evaluated any preferential and antagonistic associations with Candidatus Midichloria mitochondrii and the pathogens Borrelia burgdorferi sensu lato and Borrelia miyamotoi. Rickettsiella spp. were detected in most I. ricinus populations investigated, encompassing a wide array of climate types and environments. The infection prevalence significantly differed between geographic locations and was significantly higher in adults than in immature life stages. Phylogenetic investigations and protein characterization disclosed four Rickettsiella clades (I-IV). Close phylogenetic relations were observed between Rickettsiella strains of I. ricinus and other arthropod species. Isolation patterns were detected for Clades II and IV, which were restricted to specific geographic areas. Lastly, although coinfections occurred, we did not detect significant associations between Rickettsiella spp. and the other tick-associated bacteria investigated. Our results suggest that Rickettsiella spp. are a genetically and biologically diverse facultative symbiont of I. ricinus and that their distribution among tick populations could be influenced by environmental components.
\end{abstract}

Keywords Rickettsiella $\cdot$ Tick-borne bacteria co-infection · Facultative symbionts $\cdot$ Ixodes ricinus ecology $\cdot$ Tick-borne pathogens

\section{Introduction}

Ticks interact with multiple biotic and abiotic factors that modulate the success of their survival and development. Environmental factors - such as climate, habitat type, and host availability — are among the most limiting drivers for ticks, determining their geographical spread and abundance $[1,2]$. Moreover, ticks are involved in commensal, mutualistic, and parasitic relationships with a wide range of microbes, including bacteria, viruses, and protozoa, which can cause infectious diseases in humans and animals. Together, they compose the so-called tick microbiota [3].

\footnotetext{
Aitor Garcia-Vozmediano

aitor.garciavozmediano@unito.it

$\triangle$ Aleksandra I. Krawczyk

aleksandra.i.krawczyk@gmail.com
}

Extended author information available on the last page of the article
Among members of tick microbiota, tick-borne pathogens have sparked the greatest interest, given their worldwide impact on public and veterinary health [4-7]. However, recent advances in molecular techniques enabled the identification of complex bacterial communities residing in ticks, including symbiotic bacteria that display an important role in tick ecology and physiology [8]. In fact, some of these symbiotic bacteria are considered essential for tick survival since their absence reduces the reproductive fitness of ticks [9]; others supplement the unbalanced diet of ticks by biosynthesizing vitamins that are scarce in vertebrate blood [10, 11]. Microbial communities within ticks have been hypothesized to modulate the occurrence and diversity of tick-borne pathogens and consequently determine their transmission to vertebrate hosts [8].

Ixodes ricinus is the most widespread tick species in Europe and the primary vector of Borrelia burgdorferi sensu lato, the causative agent of Lyme borreliosis [12]. It also 
transmits Borrelia miyamotoi, an emerging human pathogen belonging to the relapsing fever group borreliae [13]. In the past years, several studies have explored I. ricinus microbiota, identifying different heritable bacteria. Among these, Candidatus Midichloria mitochondrii (hereafter $M$. mitochondrii) is one of the most abundant symbionts and widespread among several tick species. It is mainly located within the mitochondria of host ovary cells $[14,15]$, however, it has been also identified in salivary glands and Malpighian tubules, suggesting that it might play different roles in tick physiology [16]. Although there is evidence for the presence of $M$. mitochondrii DNA in vertebrate hosts of ticks, it remains unclear whether its presence in vertebrates may cause disease or may facilitate horizontal transmission [17].

Other heritable bacteria residing in Ixodes ticks are obligate intracellular bacteria of the genus Rickettsiella [18-22]. Rickettsiella spp. have been also associated with other arthropods, including insects, arachnids, and crustaceans [23-29]. Depending on the arthropod host, the infection by some Rickettsiella species was shownto hinder the hosts' development and survival [23], or manipulate host reproduction [30]. Other Rickettsiella spp. have shown a biological significance for the survival of their hosts by manipulating the host attractiveness to predators and parasitoids [31].

Relatively few studies have so far reported on Rickettsiella infection in I. ricinus [20, 32-35], and its biological role in this important vector is entirely unknown. In the present study, we examined European Ixodes ticks for the presence of Rickettsiella spp. and determined its genetic diversity, with a focus on I. ricinus. Moreover, we evaluated possible associations of Rickettsiella spp. with M. mitochondrii and the pathogens B. burgdorferi s.l. and Borrelia miyamotoi.

\section{Materials and Methods}

\section{Tick Sampling}

To evaluate the presence of Rickettsiella symbionts in I. ricinus populations, we studied a total of 4941 questing ticks from different latitudes across Europe (Appendix), which were morphologically identified to species level [36]. Northwestern and central Europe were represented by 2033 Ixodes ticks collected in green areas of Antwerp (Belgium; [37]), 999 I. ricinus from nine different forest sites across the Netherlands and 66 I. ricinus nymphs from Güterfelde, northeastern Germany, collected by dragging in April 2019. We also included $240 \mathrm{I}$. ricinus collected in two different areas from the southern United Kingdom. Northern latitudes were represented by tick populations collected in September 2018 in forested areas in Södermanland county, Sweden $(n=235)$. Finally, Southern Europe accounted for three mountain areas located in north-western and central Italy $(n=1,368)$ as previously described [38-40]. Furthermore, some specimens of questing Ixodes frontalis $(n=4)$ and Ixodes hexagonus $(n=6)$ ticks from Belgium were also included in this study.

\section{Detection of Rickettsiella Symbionts and Other Tick-Borne Bacteria}

DNA extraction from ticks of most locations was performed using ammonium hydroxide [41], except for the ticks from northwestern and central Italy from which tick DNA was extracted using DNAzol reagent (Life Technologies LTD, Warrington, UK) [40] and the QIAGEN DNeasy tissue kit (Qiagen, Hilden, Germany) [38], respectively.

All ticks were screened by multiplex polymerase chain reaction (qPCR) assays targeting the ospA and flaB genes of $B$. burgdorferi s.l. and the $f a B$ gene of $B$. miyamoto $i$ as previously described in $[42,43]$. To detect the tick symbionts Rickettsiella spp. and M. mitochondrii a multiplex qPCR protocol was designed using primers and probes described in Table 1. A sample was considered positive for Ricketsiella if at least one of the two targets, either gidA or $s u c B$, was positive. Positive qPCR-Rickettsiella samples were subjected to end-point conventional PCR targeting a 786-bp fragment of gidA gene with primers previously described in [44].

All qPCRs were carried out on a LightCycler 480 (Roche Diagnostics Nederland B.V, Almere, the Netherlands) in a final volume of $20 \mu \mathrm{l}$ with iQ multiplex Powermix, $3 \mu \mathrm{l}$ of sample, primers with end concentration of $0.2 \mu \mathrm{M}$, and probes. Positive plasmid controls and negative water controls were used on every plate tested. Cycling conditions included an initial activation of the iTaq DNA polymerase at $95{ }^{\circ} \mathrm{C}$ for $5 \mathrm{~min}$, followed by 60 cycles of a 5 -s denaturation at $95^{\circ} \mathrm{C}$ followed by a 35 -s annealing-extension step at $60{ }^{\circ} \mathrm{C}$ (ramp rate $2.2^{\circ} \mathrm{C} \mathrm{s}^{-1}$ and a single point measurement at $60{ }^{\circ} \mathrm{C}$ ) and a final cooling cycle of $37^{\circ} \mathrm{C}$ for $20 \mathrm{~s}$. To minimize contamination and false-positive samples, the DNA extraction, PCR mix preparation, sample addition, and qPCR analyses were performed in separate air-locked laboratories.

\section{Statistical Analyses}

Tick infection and coinfection prevalence and $95 \%$ binomial confidence intervals were calculated using RStudio software v1.1.463 [45]. Moreover, we compared the frequency of tick-borne bacterial infections and coinfections among the European countries investigated, including sampling areas within the single regions, as well as between tick life stages (nymphs and adults) using Pearson's chi-squared test. Finally, we used the Kappa ( $\kappa$ ) statistic to assess the association by quantifying coinfections of Rickettsiella spp. with 
Table 1 Marker genes with qPCR primers and probes used for amplification

\begin{tabular}{|c|c|c|c|c|}
\hline Tick symbiont & Gene acronym & Function of gene product & PCR primers & $\begin{array}{l}\text { Length of } \\
\text { amplified } \\
\text { sequences (bp) }\end{array}$ \\
\hline \multirow[t]{6}{*}{ Rickettsiella spp. } & \multirow[t]{3}{*}{ gidA } & \multirow[t]{3}{*}{$\begin{array}{l}\text { Glucose inhibited cell division protein } \\
\text { A }\end{array}$} & $\begin{array}{l}\text { fwd: 5'- TGT AAT CCT TGA GTC } \\
\text { TGA TCG T }\end{array}$ & \multirow[t]{3}{*}{196} \\
\hline & & & $\begin{array}{l}\text { rev: 5'- CAA ACC GAT ATG AAT } \\
\text { TTT TCC GG }\end{array}$ & \\
\hline & & & $\begin{array}{l}\text { probe: } 5^{\prime}-\text { ATTO520-TAG TTG GTG } \\
\text { TGG TAA CGC AAA TGG GGT- } \\
\text { BHQ2 }\end{array}$ & \\
\hline & \multirow[t]{3}{*}{$\operatorname{sucB}$} & \multirow[t]{3}{*}{$\begin{array}{l}\text { Dihydrolipoamide succinyl-transferase } \\
\text { component E2 }\end{array}$} & $\begin{array}{l}\text { fwd: 5'- GAT CAA CCC TCT CAA } \\
\text { TCA GC }\end{array}$ & \multirow[t]{3}{*}{76} \\
\hline & & & $\begin{array}{l}\text { rev: 5'- GCC AAA TGG GTG TCA } \\
\text { CTA T }\end{array}$ & \\
\hline & & & $\begin{array}{l}\text { probe: 5'- ATTO647- CAC CCG TCG } \\
\text { CAG AAA AAA CTA AAC CTG- } \\
\text { BHQ2 }\end{array}$ & \\
\hline \multicolumn{5}{|c|}{ Midichloria mitochondrii } \\
\hline & \multirow[t]{3}{*}{ gyrB } & \multirow[t]{3}{*}{ Gyrase subunit B } & $\begin{array}{l}\text { fwd: 5'- CTT GAG AGC AGA ACC } \\
\text { ACC TA }\end{array}$ & \multirow[t]{3}{*}{145} \\
\hline & & & $\begin{array}{l}\text { rev: 5'- CAA GCT CTG CCG AAA } \\
\text { TAT CTT }\end{array}$ & \\
\hline & & & $\begin{array}{l}\text { probe: 5'- ATTO424- GAG GGC GGA } \\
\text { GTC AAA GAA TTT GTC CAC } \\
\text { G-BHQ1 }\end{array}$ & \\
\hline
\end{tabular}

tick-borne pathogens (B. burgdorferi s.1. and B. miyamotoi) and $M$. mitochondrii [46].

\section{Phylogenetic Analyses}

Forward and reverse nucleotide sequences for each Rickettsiella gidA amplicon were accurately assembled and manually corrected into final nucleotide sequences of $723 \mathrm{bp}$ using Geneious Prime (version 2020.0.4) software. These were aligned to available reference gidA sequences from different arthropod species, including ticks from North America, such as Ixodes angustus (GenBank accession n. HG792871), Ixodes kingi (HG792872), Ixodes sculptus (HG792873) and Ixodes woodi (JQ070345), other arachnid species (KU597421) and several insects belonging to the orders Coleoptera and Isopoda (JQ679309, JX406182, JN56568789-91, JF288927). A Coxiella burnetii (AE016828.3) sequence was used as an outgroup given its evolutionary relationship with Rickettsiella spp. The nucleotide alignment was performed using ClustalW [47] respecting the coding frame. This method avoids nucleotide sequence misreading based on the conversion of nucleotide sequences into their corresponding peptide sequences which, in turn, will be eventually translated back into the nucleotide sequences they have originated from [48]. Nucleotide and amino acid diversities were calculated among all the analysed samples and expressed as percentage. Nucleotide alignment as well as the amino acid variable positions was evaluated in order to investigate the possible population structure. We assessed the phylogenetic relationships among Rickettsiella positive samples and reference sequences using a MCMC Bayesian approach by using the GTR substitution model [49] embedded in MrBayes software v3.2.7a [50]. The resulting consensus tree was viewed and edited using FigTree v1.4.4 [51].

\section{Results}

\section{Occurrence of Rickettsiella spp. in Different European Regions}

Rickettsiella spp. was widespread in most of the $I$. ricinus populations, although its occurrence between geographic locations varied (Pearson's Chi-squared test, $p<0.001$ ). Regions from western Europe showed the highest infection rates, except for the tick population from Germany, in which the bacterium was not detected at all. Tick populations from Belgium reached a prevalence of nearly $90 \%$, followed by around $60 \%$ and $50 \%$ of infection observed in populations from the Netherlands and UK, respectively (Table 2). We conversely recorded the lowest infection rates in $I$. ricinus ticks from northern and southern latitudes (Sweden and Italy), with less than $20 \%$ prevalence (Table 2). This variability was also evident within the single 
Table 2 Infection prevalence (\%) and 95\% CIs of Borrelia burgdorferi s.l., Borrelia miyamotoi, Midichloria mitochondrii, and Rickettsiella spp. in Ixodes ricinus by region and tick-life stage

\begin{tabular}{|c|c|c|c|c|c|}
\hline \multirow[t]{2}{*}{ Country } & \multirow[t]{2}{*}{ Tick life stage tested $(n)$} & \multicolumn{2}{|l|}{$\begin{array}{l}\text { Pathogen infection } \\
\text { (\%) }[95 \% \mathrm{CI}]\end{array}$} & \multicolumn{2}{|l|}{$\begin{array}{l}\text { Symbiont infection } \\
(\%)[95 \% \mathrm{CI}]\end{array}$} \\
\hline & & B. burgdorferi s.l & B. miyamotoi & M. mitochondrii & Rickettsiella spp. \\
\hline \multirow[t]{5}{*}{ Belgium } & Overall infection & $18.4[16.7-20.1]$ & $1.6[1.1-2.3]$ & $77.9[75.7-79.4]$ & $88.6[87.2-90.0]$ \\
\hline & $\mathrm{L}$ & - & - & - & - \\
\hline & $\mathrm{N}(n=1,771)$ & $16.8[15.1-18.6]$ & $1.5[1.0-2.1]$ & $77.7[75.7-79.6]$ & $87.6[86.0-89.1]$ \\
\hline & $\mathrm{F}(n=126)$ & $30.9[23.0-39.8]$ & $3.2[0.9-7.9]$ & $98.4[94.4-99.8]$ & 94.4 [88.9-97.7] \\
\hline & $\mathrm{M}(n=136)$ & $28.7[21.2-37.1]$ & $2.2[0.5-6.3]$ & $61.8[53.0-70.0]$ & $96.3[91.6-98.8]$ \\
\hline \multirow[t]{5}{*}{ UK } & Overall infection & $7.9[4.8-12.1]$ & $0.8[0.1-3.0]$ & $48.7[42.3-55.3]$ & $47.9[41.4-54.4]$ \\
\hline & $\mathrm{L}$ & - & - & - & - \\
\hline & $\mathrm{N}(n=218)$ & $7.3[4.2-11.6]$ & $0.9[0.1-3.3]$ & $45.0[38.2-51.8]$ & $45.0[38.2-51.8]$ \\
\hline & $\mathrm{F}(n=22)$ & $13.6[2.9-34.9]$ & $0[0-15.4]$ & $86.4[65.1-97.1]$ & $77.3[54.6-92.2]$ \\
\hline & M & - & - & - & - \\
\hline \multirow[t]{5}{*}{ Germany } & Overall infection & $6.1[1.7-14.8]$ & $1.5[0.03-8.2]$ & $36.4[24.9-49.1]$ & $0[0-0.5]$ \\
\hline & $\mathrm{L}$ & - & - & - & - \\
\hline & $\mathrm{N}(n=66)$ & $6.1[1.7-14.8]$ & $1.5[0.04-8.2]$ & $36.4[24.9-49.1]$ & $0[0-0.5]$ \\
\hline & $\mathrm{F}$ & - & - & - & - \\
\hline & M & - & - & - & - \\
\hline \multirow[t]{5}{*}{ Italy } & Overall infection & 15.2 [13.3-17.2] & $0.6[0.2-1.2]$ & $68.9[66.4-71.4]$ & $3.1[2.2-4.1]$ \\
\hline & $\mathrm{L}$ & - & - & - & - \\
\hline & $\mathrm{N}(n=1,351)$ & $14.5[12.6-16.5]$ & $0.5[0.2-1.1]$ & 69.4 [66.8-71.9] & $2.5[1.7-3.5]$ \\
\hline & $\mathrm{F}(n=17)$ & $38.1[23.6-54.4]$ & $1.7[0.04-8.4]$ & $54.8[38.7-70.2]$ & $21.4[10.3-36.8]$ \\
\hline & M & - & & & \\
\hline \multirow[t]{5}{*}{ The Netherlands } & Overall infection & $12.3[9.9-15.2]$ & $1.6[0.9-2.6]$ & $73.6[63.0-82.4]^{*}$ & $61.9[58.0-65.7]$ \\
\hline & $\mathrm{L}(n=367)$ & $0.3[0.0-1.5]$ & $1.4[0.4-3.2]$ & $84.2[80.1-87.8]$ & $36.8[31.8-41.9]$ \\
\hline & $\mathrm{N}(n=589)$ & $11.6[9.1-14.4]$ & $1.9[0.9-3.3]$ & 74.4 [63.2-83.6] & 62.4 [58.4-66.3] \\
\hline & $\mathrm{F}(n=21)$ & $9.5[1.2-30.4]$ & $0[0-16.1]$ & $100[54.1-100]$ & $57.1[34.0-78.2]$ \\
\hline & $\mathrm{M}(n=22)$ & 36.4 [17.2-59.3] & $0[0-15.4]$ & $0[0-84.2]$ & $54.5[32.2-75.6]$ \\
\hline \multirow[t]{5}{*}{ Sweden } & Overall infection & 23.0 [17.8-28.9] & $0.9[0.1-3.0]$ & $62.1[55.6-68.4]$ & 16.2 [11.7-21.5] \\
\hline & $\mathrm{L}$ & - & - & - & - \\
\hline & $\mathrm{N}(n=216)$ & $23.6[18.1-29.8]$ & $0.9[0.1-3.3]$ & $63.0[56.1-69.4]$ & $14.8[10.4-20.3]$ \\
\hline & $\mathrm{F}(n=10)$ & $10.0[0.3-44.5]$ & $0[0-30.8]$ & 100 [66.3-100] & $20.0[2.5-55.6]$ \\
\hline & $\mathrm{M}(n=9)$ & $22.2[2.8-60.0]$ & $0[0-30.8]$ & $0[0-30.8]$ & $33.3[7.5-70.1]$ \\
\hline
\end{tabular}

\footnotetext{
* Only 87 out of 999 ticks were tested for M. mitochondrii
}

Note: Names of tick life stage categories were abbreviated: L (larvae), N (nymphs), F (female) and M (male); “-” indicates no specimens were tested for the corresponding tick life stage category

regions in the countries where different areas were sampled (Table 3); infection rates differed significantly among study sites in the Netherlands $(p<0.001)$, UK $(p<0.01)$ and Italy $(p<0.001)$. The bacterium occurred in all Dutch tick populations $(n=9)$, with a prevalence ranging between $16.1 \%$ (95\% CI $=7.6-28.3)$ and $99.0 \%$ (95\% CI $=94.3-100)$. Moderate infection rates were observed in the two tick populations from the UK, with $38.3 \%(95 \% \mathrm{CI}=29.6-47.6)$ and $57.5 \%$ (95\% CI $=48.1-66.5)$ of infected ticks. The symbiont occurred in a low proportion of I. ricinus ticks collected in mountain areas from Italy, and only in one out of three locations investigated (Table 3; 11.8\% positives out of $296 I$. ricinus tested). Lastly, Rickettsiella DNA was also detected in all four I. frontalis and six I. hexagonus specimens tested from Belgium.

\section{Rickettsiella spp. Through Ixodes ricinus Ontogeny}

Adults $(n=389)$ and nymphs $(n=4185)$ were analysed, as well as a sample of 367 larvae from the Netherlands. Larvae, nymphs, and adult ticks harboured Rickettsiella spp. (Table 2), but the infection exhibited substantial changes according to tick life stage $(p<0.001)$ and the odds of infection for adults doubled those for nymphs $(\mathrm{OR}=2.4$, $95 \% \mathrm{CI}=1.7-3.4)$. Only in the Netherlands, infection in nymphs slightly prevailed over the adults' prevalence, but 
Table 3 Rickettsiella spp. infection prevalence (\%) and 95\% CIs in Ixodes ricinus stratified by location

\begin{tabular}{llll}
\hline Region & Location & N ticks tested & $\%[95 \% \mathrm{CI}]$ \\
\hline The Netherlands & Amsterdamse Waterleiding Duinen & 349 & $52.7[47.3-58.1]$ \\
& Bergherbos & 56 & $16.1[7.6-28.3]$ \\
& Buunderkamp & 171 & $21.6[15.7-28.6]$ \\
& Duin en Kruidberg & 96 & $99.0[94.3-99.7]$ \\
& Deelerwoud & 64 & $31.3[20.2-44.1]$ \\
& Herperduin & 48 & $18.8[8.9-32.6]$ \\
& Kremboong & 88 & $88.6[80.1-94.4]$ \\
& Stameren & 48 & $37.5[24.0-52.6]$ \\
Italy & Zwanemeerbos & 80 & $95.0[87.7-98.6]$ \\
& Alpi Cozie Natural Park & 785 & $0[0-1.0]$ \\
& Aosta Valley & 296 & $11.8[8.4-16.1]$ \\
Germany & Tuscany & 287 & $0[0-1.0]$ \\
UK & Güterfelde & 66 & $0[0-1.0]$ \\
Sweden & Salisbury & 120 & $57.5[48.4-66.5]$ \\
Belgium & Dartmoor & 120 & $38.3[29.6-47.6]$ \\
\hline & Södermanlands & 235 & $16.2[11.7-21.5]$ \\
& Antwerp & 2033 & $88.6[87.1-89.9]$ \\
\hline
\end{tabular}

the difference was not statistically significant $(p=0.5)$. Moreover, $36.8 \%$ (95\% CI =31.8-41.9) of Dutch larvae tested qPCR-positive for Rickettsiella spp. Rickettsiella infection was comparable in males and females (Pearson's chi-squared test, $p=0.9)$, with a prevalence of $80.9 \%$ (95\% CI $=74.4-86.3)$ and $81.7 \%$ (95\% CI $=75.4-87.0)$, respectively.

\section{Genetic Diversity of Rickettsiella spp.}

We successfully obtained 263 gidA gene (723 bp) nucleotide sequences from I. ricinus from most European regions in the study, and one from I. frontalis collected in Belgium. Overall, gidA sequences showed a high level of similarity, with 85 of 100 sequences from Belgium, 65/98 from the Netherlands, 37/52 from the UK, 6/8 from Sweden, and 2/5 from Italy having $100 \%$ of identity. Given the amount of gidA sequences produced and the high degree of similarity observed between them, we selected 115 sequences comprising all nucleotide sequences with different levels of dissimilarity $(n=75)$, and a batch of those sharing $100 \%$ of identity $(n=40)$, representative for each European region.

Phylogenetic tree topology showed a clustering of the Rickettsiella population into four well-defined clades (Fig. 1) which, at time, exhibited different frequencies $(p<0.001)$. Rickettsiella-Clade I represented the largest group observed comprising $81.7 \%$ (95\% CI $=76.5-86.2)$ of the entire population followed by Clade III $(12.2 \%$; 95\% CI =8.5-16.8). Rickettsiella-Clades II and IV, on the other hand, respectively accounted for $2.7 \%(95 \% \mathrm{CI}=1.1-5.4)$ and $3.1 \%(95 \%$ $\mathrm{CI}=1.3-5.9$ ) of the symbiont population, thus representing the least frequent Rickettsiella Clades detected in I. ricinus ticks. We also identified a Rickettsiella spp. from a single $I$. frontalis nymph that clustered within Rickettsiella-Clade I and showed 99.6-100\% of identity with Rickettsiella strains described from I. ricinus. Analysis of Rickettsiella sequences from North American hard ticks showed that only a Rickettsiella spp. recorded in I. angustus was closely related to those of I. ricinus and clustered within Clade III. Rickettsiella sequences identified in I. kingi, I. sculptus and I. woodi gathered within a single clade that was distantly related to those observed in I. ricinus (Fig. 1).

This classification relied upon the genetic structure observed in parallel at nucleotide and amino acids (AA) levels. Overall, Rickettsiella populations within the same clade consistently experienced a low degree of variability since the uncorrected $p$-distance ( $u p$ ) averaged around $0.77 \%$ (min.-max. $=0-2.68$; Table S1, Supporting Information). For instance, Clade I constituted the most conserved clusters, despite being composed of Rickettsiella from different geographic areas and harbouring sequences obtained from different arthropod species. Clade I-gidA sequences are closely related to Candidatus Rickettsiella isopodorum reported in terrestrial isopods species (JQ679309; JX406182) from Germany, sharing a high level of identity (>95\%). Rickettsiella-clades differentiation was sustained not only by the genetic distance, which showed mean values below 13.6\% (Table S1, Supporting Information) among groups, but also by the AA composition they encoded. Using a 241 AA sequence of Coxiella burnetii as a reference, we could identify a total of 28 variable sites in the Rickettsiella AA sequences, which enabled us to determine the protein sequence motifs that characterized the single clades (Table S2, Supporting Information). 


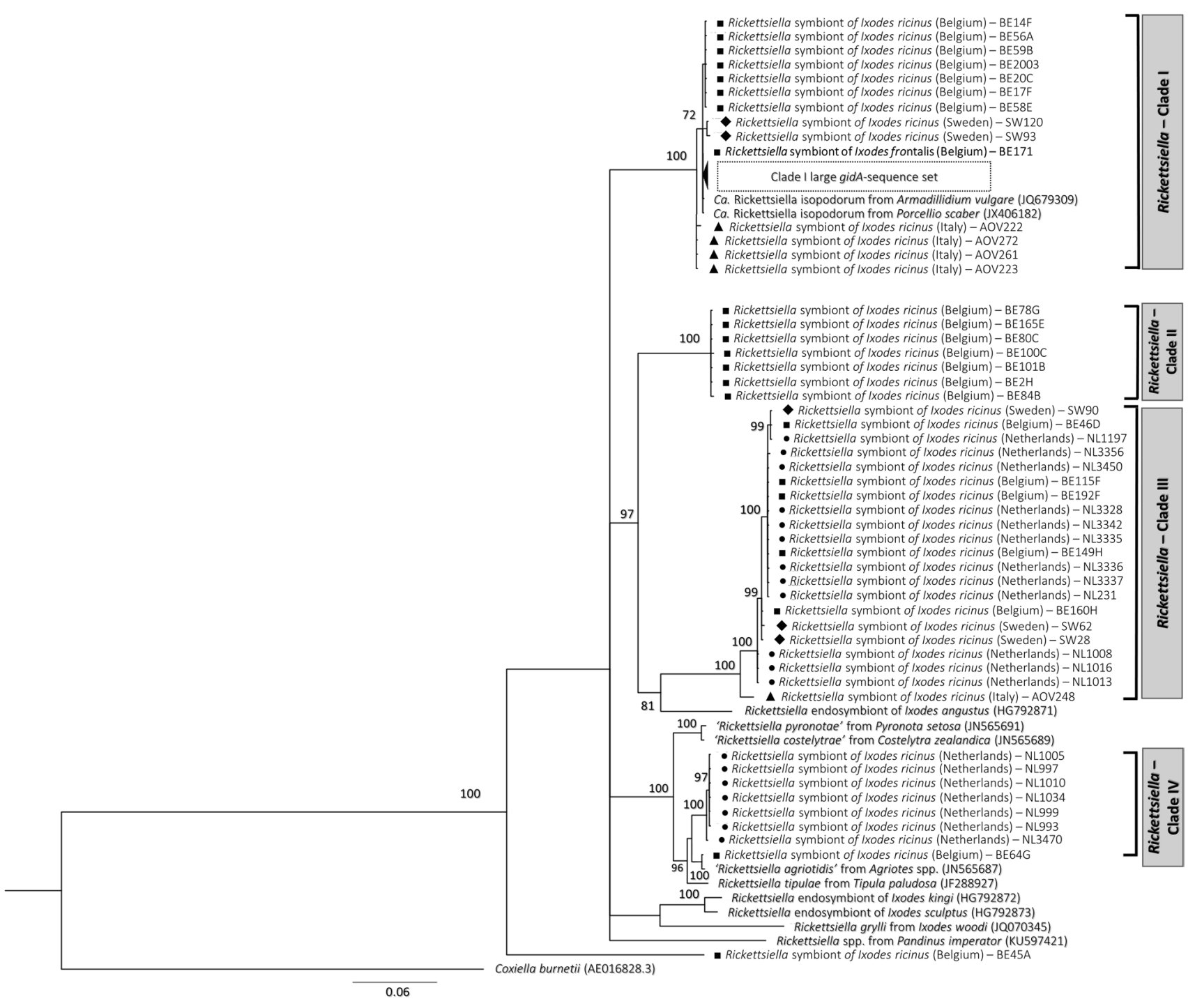

Fig. 1 Phylogenetic tree of gidA gene of Rickettsiella spp. obtained from questing Ixodes ricinus populations collected from different European regions. The tree was built by using GTR substitution model $(\gamma=0.05)$ and nodal support is given as a posterior probability for Bayesian Inference under percentage format; only probability values above 70 are shown next to the internal nodes. Coxiella burnetii was used as the outgroup. Reference sequences are identified by Gen-

The gidA-AA sequence profiling mirrored the genetic variability already observed within each Rickettsiella-clades. Clades I and II showed the highest degree of conservation since only an Ala-Thr substitution was detected, occurring at positions 140 and 52 of the reference sequence, respectively. By contrast, we detected a larger number of substitutions within Clades III and IV; in particular, sequences clustered into Clade III displayed Ala/Thr-Pro/ Ser-Lys/Asp/Glu-Tyr/His substitutions at positions 13-80-124-148, while Clade IV exhibited Ala/Ser-Glu/ Lys-Lys/Arg substitutions at positions 72-115-152.
Bank accession number enclosed in parentheses. Amplicons obtained in the study are indicated with a black symbol representing the region of provenance: Belgium ( $\mathbf{\square})$, Italy ( $\boldsymbol{\Delta})$, the Netherlands $(\mathbf{O})$, Sweden $(\diamond)$, and the UK $(\nabla)$. A large gidA sequence set from RickettsiellaClade I was removed from the tree for readability purposes, containing a total of 64 sequences identified in I. ricinus from Belgium $(n=10)$, the Netherlands $(n=28)$, UK $(n=25)$, and Sweden $(n=1)$

From a geographic point of view, different distribution patterns of each Rickettsiella clade were seen (Fig. 2). The most prevalent population, Clade I, was distributed among all I. ricinus investigated and was the only Rickettsiella clade detected in the British study sites. Rickettsiella-Clade III was detected in all study regions except for UK and prevailed in I. ricinus from Sweden. These two clades concurrently circulated with Rickettsiella-Clades II and IV in I. ricinus from closely related north-western regions. Clade II was only detected in ticks from Belgium study sites, whereas Clade IV was discovered in tick populations from the Netherlands and, to a lesser extent, Belgium. Rickettsiella spp. 


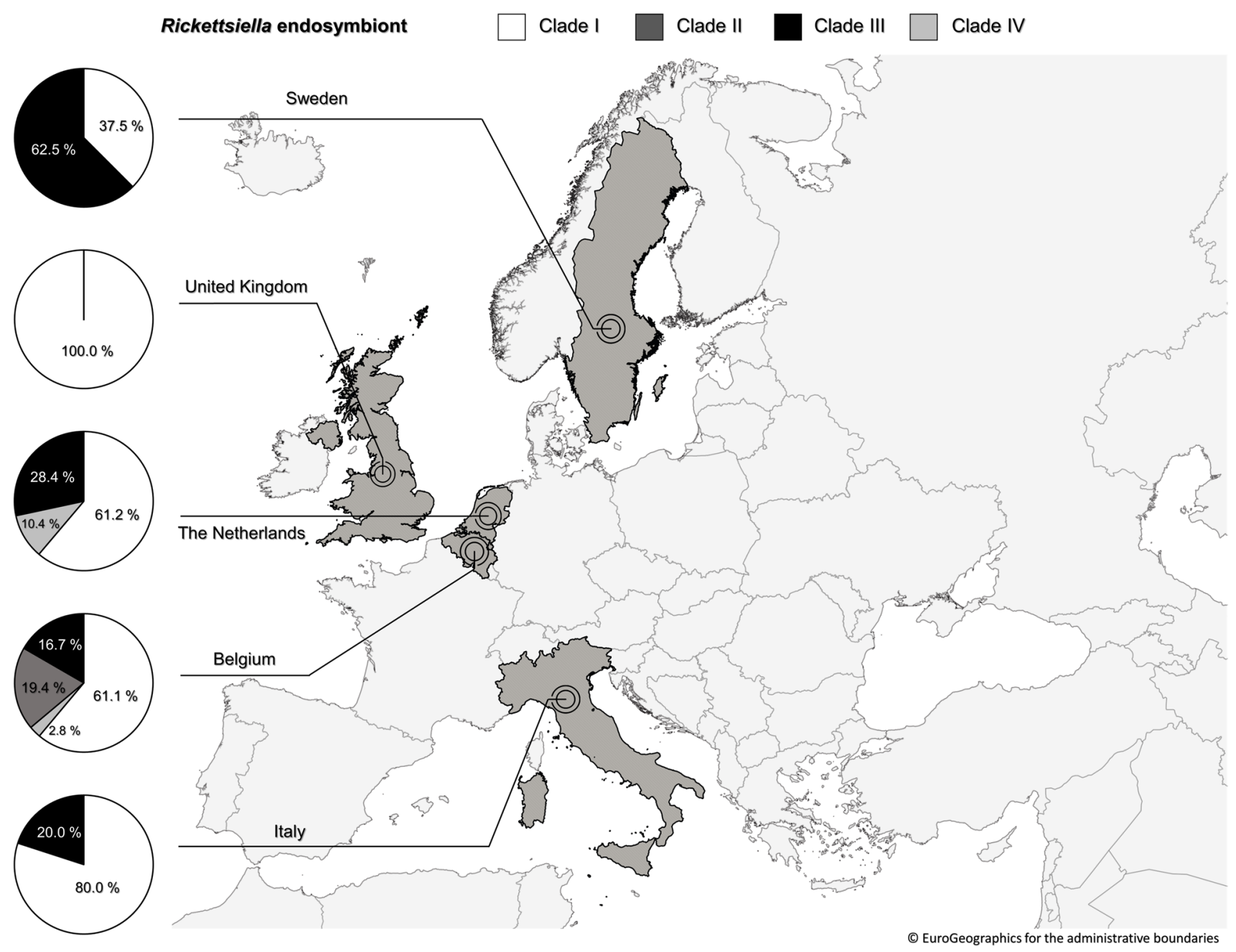

Fig. 2 Geographical distribution and proportion of Rickettsiella-clades (I-IV) identified in I. ricinus populations from Belgium, Italy, the Netherlands, Sweden, and the UK

from Clade IV were closely related (95\% identity) with $R$. agriotidis (JN565687), $R$. costelytrae (JN565689), and $R$. pyronotae (JN565691) that were recorded in different beetle species from Germany and New Zealand.

\section{Relationship of Rickettsiella spp. with Other Tick-Borne Microorganisms}

Both investigated tick-borne pathogens, B. burgdorferi s.l. and $B$. miyamotoi, were present in all study areas. The prevalence of $B$. burgdorferi s.l. varied among the studied tick populations and geographic locations (Pearson's chi-squared test, $p<0.001$ ), with Sweden and Belgium showing the highest infection prevalence (Table 2). Borrelia burgdorferi s.l. infection prevalence was associated with the tick life stage. It was significantly higher in adult ticks compared to nymphs $(p<0.0001)$. The odds of $B$. burgdorferi s.l. infection for adults, in fact, doubled those for nymphs $(\mathrm{OR}=2.1 ; 95 \% \mathrm{CI}=1.6-2.7)$. Borrelia burgdorferi s.l. prevalence in adult ticks in Belgian and Italian tick populations (29.8\% and $38.1 \%$, respectively) was also significantly higher than the prevalence in nymphs $(16.8 \%$ and $14.5 \%$, respectively; $p<0.001$ ).

Neither geographic location nor tick life stage was associated with the occurrence of $B$. miyamotoi in ticks. The infection prevalence of $B$. miyamotoi was low in all studied areas (Table 2) and did not differ among regions $(p=0.07)$. The pathogen was observed in nymphs from all the investigated countries, but only in adults from Belgium (2.7\%; $95 \% \mathrm{CI}=1.1-5.4)$ and Italy $(1.7 \%$; 95\% CI $=0.06-12.6)$.

A generally high $M$. mitochondrii prevalence was detected (Table 2). It significantly differed among the regions $(p<0.001)$. Infection rates below $50 \%$ were recorded in Germany $(36.4 \%$; $95 \% \mathrm{CI}=24.9-49.1)$ and UK $(48.7 \%$; 95\% CI $=42.3-55.3)$. Midichloria infection was not associated with the tick life stage ( $p=0.38)$, although adults and 
nymphs showed different infection rates depending on the country where they were collected (Table 2). In regions for which information on the sex of adults was available (Belgium, the Netherlands, UK, and Italy), the odds of M. mitochondrii infection were significantly higher in female ticks compared to that in males $(\mathrm{OR}=18.0 ; 95 \% \mathrm{CI}=7.8-48.4)$.

We detected the highest rates of bacterial coinfections in ticks from Belgium (around 75\%), followed by the UK and Sweden (Table 4 and 5). While around 70-80\% of coinfected ticks from Belgium and UK exclusively involved symbionts, over $75 \%$ of coinfections from the other countries involved at least one pathogen and one symbiont (Table 4). In Germany, only two out of 27 infected ticks were coinfected, with $B$. burgdorferi s.l. and M. mitochondrii.

We detected all possible combinations of coinfections. Coinfections with two bacteria were the most frequently observed in all regions. Belgium recorded the highest rates of Midichloria-Rickettsiella coinfections, affecting around $75 \%$ of the tick population. In countries where coinfections in ticks predominantly involved pathogens (B. burgdorferi s.l. and $B$. miyamotoi) in combination with symbionts ( $M$. mitochondrii and Rickettsiella spp.), B. burgdorferi s.l. played the major role since it was far more prevalent than $B$. miyamotoi. Around $60-70 \%$ of the coinfections observed in Italy, Netherlands and Sweden were constituted by B. burgdorferi s.l. and at least one symbiont. As regards multiple coinfections, with more than two bacteria, the combination B. burgdorferi s.l.-M. mitochondrii-Rickettsiella spp. was the most prevalent. Coinfections with all four investigated bacteria were recorded in ticks from Belgium, Italy, the Netherlands, and Sweden.

The life stage of I. ricinus was not associated with the frequency of coinfections by two bacterial species, while multiple coinfections, with three bacteria or more, markedly prevailed in adult ticks compared to nymphs $(p<0.001)$.

Our results did not show significant associations between Rickettsiella spp. and B. burgdorferi s.l., B. miyamotoi, and $M$. mitochondrii. The highest $\kappa$-values obtained indicated a 'very low agreement' $(\kappa=0.0-0.20)$, and corresponded with the following positive associations: $M$. mitochondrii with Rickettsiella spp. in ticks from UK $(\kappa=0.15$; $95 \%$ $\mathrm{CI}=0.024-0.27)$, and B. burgdorferi s.l. with Rickettsiella spp. in Italy $(\kappa=0.11 ; 95 \% \mathrm{CI}=0.051-0.17)$.

\section{Discussion}

This study contributes to the limited available knowledge about Rickettsiella symbionts in Ixodes ticks throughout Europe. Our results confirm the broad distribution of this heritable bacteria among different tick populations, encompassing a wide array of habitat types and climatic environments. In particular, we observed Rickettsiella spp. in geographically distant populations of I. ricinus, in which they displayed significantly different infection rates and highly diverse genetic features.

Intracellular bacteria of the genus Rickettsiella seem common in Ixodes ticks, though they have been also detected in metastriate tick species such as Amblyomma spp. and Haemaphysalis spp. [52], and soft ticks [32]. Rickettsiella spp. have been reported in Ixodes ticks from all over the world, including I. kingi, I. sculptus, I. angustus, I. woodi, and I. scapularis from North America [18, 21, 53]; I. tasmani from Australia [19]; and I. uriae from different locations of the northern and southern hemispheres [22]. In addition, Rickettsiella spp. have recently been detected in the tree-hole tick

Table 4 Overall coinfection rates in I. ricinus ticks according to the geographic areas of origin and to the tick-borne bacteria involved

\begin{tabular}{|c|c|c|c|c|c|c|c|}
\hline \multirow[t]{2}{*}{ Country } & \multirow{2}{*}{$\begin{array}{l}\% \text { Coinfection } \\
{[95 \% \mathrm{CI}]}\end{array}$} & \multicolumn{6}{|c|}{ Type of coinfection $(\%)[95 \% \mathrm{CI}]$} \\
\hline & & $\mathrm{B}-\mathrm{Bm}$ & $\mathrm{B}-\mathrm{M}$ & $\mathrm{B}-\mathrm{R}$ & $\mathrm{Bm}-\mathrm{M}$ & $\mathrm{Bm}-\mathrm{R}$ & $\mathrm{M}-\mathrm{R}$ \\
\hline Belgium & $75.6[73.7-77.5]$ & $0.7[0.4-1.3]$ & $20.7[18.6-22.9]$ & $22.1[20.0-24.3]$ & $1.9[1.2-2.7]$ & $1.9[1.3-2.8]$ & $94.1[92.8-95.3]$ \\
\hline UK & $42.8[35.3-50.5]$ & $0[0-1.0]$ & $13.5[6.7-23.5]$ & $14.9[7.7-25.0]$ & $0[0-1.0]$ & $0[0-1.0]$ & $87.8[78.2-94.3]$ \\
\hline Germany & $7.4[0.9-24.3]$ & $0[0-1.0]$ & $100[15.8-100]$ & $0[0-1.0]$ & $0[0-1.0]$ & $0[0-1.0]$ & $0[0-1.0]$ \\
\hline Italy & $19.2[16.7-21.7]$ & $2.6[0.9-6.0]$ & $86.3[80.6-90.9]$ & $7.9[4.5-12.7]$ & $2.6[0.9-6.0]$ & $1.1[0.1-3.8]$ & $18.4[13.2-24.7]$ \\
\hline The Netherlands & $15.3[12.1-18.9]$ & $2.8[0.3-9.8]$ & $15.5[8.0-26.0]$ & $59.2[46.8-70.7]$ & $4.2[0.9-11.9]$ & $11.3[5.0-21.0]$ & $31.0[20.5-43.1]$ \\
\hline Sweden & $33.5[26.6-41.0]$ & $1.7[0.04-9.1]$ & $61.0[47.4-73.5]$ & $18.6[9.7-30.9]$ & $3.4[0.4-11.7]$ & $1.7[0.04-9.1]$ & $30.5[19.2-43.9]$ \\
\hline
\end{tabular}

Note: B, Borrelia burgdorferi s.1.; Bm, Borrelia miyamotoi; M, Midichloria mitochondrii; R, Rickettsiella spp 
I. arboricola $[54,55]$. To date, however, there are relatively few records of Rickettsiella infection in I. ricinus in Europe [20, 32-35].

The prevalence of Rickettsiella spp. in I. ricinus in our study varied across its geographic range. This finding is in line with previous large-scale studies concerning the polar seabird tick, I. uriae, in which Rickettsiella prevalence ranged from 3 to 24\% [22], and the Canadian I. sculptus, where the infection rate averaged from 2 to $42 \%$, according to the geographic location [21]. We recorded a higher prevalence in I. ricinus from western Europe, where Rickettsiella infection rate fluctuated between 48 and $89 \%$. Lower prevalence rates were recorded for tick populations collected from the more northern and southern latitudes here investigated (16\% and 3\%, respectively). However, sampling differed in the studied countries, including different areas within the Netherlands, UK, and Italy versus unique sampling locations in Germany, Sweden and Belgium, and this could have influenced the detected prevalence.

Our results suggest that Rickettsiella spp. is a facultative symbiont of I. ricinus, and its infection rate varies depending on the environmental context. Also, the variable Rickettsiella infection rates in different tick species and populations might result from species-specific ecology and behaviour. For instance, I. uriae and I. sculptus generally live near their vertebrate hosts $[36,56]$, which might ensure the successful development and survival of ticks. In these circumstances, the cost of bearing a bacterial symbiont could outweigh the benefits potentially provided by the symbiont, leading to a low infection rate. Conversely, I. ricinus is exposed to a constantly changing environment [57]. The exophilic lifestyle hypothetically requires/facilitates relationships with facultative symbionts, which depending on environmental conditions, affect a variety of phenotypes of their hosts. Consequently, this could be one of the explanations for a significantly higher infection rate of Rickettsiella spp. observed in I. ricinus than in other tick species.

Moreover, environmental factors have been reported to affect the composition of microbial communities residing in I. ricinus [34, 35, 58]. Constant interactions between ticks and the immediate environment could lead to bacteria acquisition directly from the soil and vegetation $[34,58$, 59], where they spend most of their life. Thus, differences in habitat characteristics might determine either the presence or absence of certain microbial taxa in different tick populations [20]. Accordingly, we may hypothesize that climate and habitat type could influence the spatial distribution of Rickettsiella spp., limiting its occurrence to local environments. For example, we observed remarkable differences in Rickettsiella distribution in mountain areas from the northwestern Alps: despite having similar habitat characteristics, we only detected the symbiont in one out of the two populations examined, in which $11.8 \%$ of the ticks were infected. Local microclimatic habitats might justify these differences. In fact, recent studies carried out in areas of the Swiss Alps reported a mean Rickettsiella prevalence of $63 \%$ in I. ricinus, uncovering a good correlation between tick abundance and precipitation with the occurrence of the bacterium [35]. However, we cannot rule out that the observed differences in Rickettsiella prevalence and diversity are stochastic events.

Essential biological processes of ticks, such as feeding and moulting, also affect the composition of tick microbiota [60] and may result in changes in microbial richness [58, 61]. In this study, we detected Rickettsiella spp. in I. ricinus larvae, nymphs, and adults, suggesting that the symbiont is maintained through successive life stages. Although no differences related to sex were observed, the prevalence was significantly higher in adults. As it has been indicated for other tick species [54], Rickettsiella sp. infection is possibly advantageous to ticks, increasing the survival success of infected individuals to the following life stage. Alternatively, the increased prevalence of Rickettsiella spp. in adults might result from an occasional horizontal transmission occurring, for example, via co-feeding of infected and uninfected ticks. Therefore, multiple feedings could increase the possibility of acquiring the symbiont. Nevertheless, in both scenarios, the subsequent transmission from adults to the offspring is hampered to some extent as we observe lower prevalence in larvae. To understand the transmission dynamics of Rickettsiella spp., future studies should investigate Rickettsiella sp. prevalence on a temporal scale and the role of vertebrates in propagating the symbiont in tick populations.

We detected an extensive genetic diversity of Rickettsiella spp. infecting I. ricinus. Four different clades composed the genetic structure of this symbiont, with some of them being associated with specific geographic areas. The diversity of Rickettsiella spp. was reported in other Ixodes species; for instance, Duron et al. [22] reported up to 12 genetically distinct strains in I. uriae, while three different 16S rRNA haplotypes were observed to coexist within I. tasmani populations [19]. On the other hand, only one Rickettsiella strain was reported for I. angustus, I. sculptus, 
and $I$. kingi, but in this study, the sample size was limited [21].

We acknowledge some limits with regard to gidA gene marker employed for this study. Relatively few gidAreference sequences can be gathered from the GenBank database, thus preventing comparisons with Rickettsiella sequences already detected in other I. ricinus populations and in different arthropod species. Notwithstanding, gidA gene has been reported as a good marker to infer in the phylogeny of this genus, in particular at the infrageneric level [62]. Rickettsiella strains here identified, besides being genetically diverse, were also biologically different, as supported by the protein sequence motifs that defined each clade. These results may indicate that different Rickettsiella strains could have different roles in the life cycle of ticks. For example, it was suggested that Rickettsiella infection may affect tick reproduction in lab-reared colonies of $I$. woodi [18], while such effects were not related to the occurrence of Rickettsiella spp. in I. arboricola [55]. Moreover, some Rickettsiella strains have been historically considered entomopathogenic [23, 62], whereas other strains are facultative mutualist in their hosts [31, 63-65]. Whole-genome sequencing could possibly help in the identification and taxonomic classification of tick symbionts and in the evaluation of their biological relationship with ticks. For instance, this method could particularly help in clarifying the taxonomic attribution of Diplorickettsia, which was described as a new bacteria genus of $I$. ricinus [66], but is nested within the Rickettsiella genus $[22,67]$. However, difficulties in isolation and cultivation still hamper the study of these microorganisms.

The close phylogenetic relations between Rickettsiella strains of I. ricinus and of other arthropods denotes the possibility of horizontal transmission among different arthropod species. Duron et al. [22] disclosed similar results in Rickettsiella strains identified in I. uriae, arguing that the symbiont might combine both vertical and horizontal transfers to ensure its maintenance and global distribution within arthropod communities. On the other hand, the specific natural environment, together with factors intrinsic to the tick hosts, might have significantly contributed to the evolution of Rickettsiella spp. In fact, isolation patterns were evident for some Rickettsiella populations: specific evolutionary forces experienced by I. ricinus and its symbionts may support the unexpected high variability observed in Rickettsiella populations from certain locations of central-western Europe. Consequently, further studies should investigate whether the genetic diversity of Rickettsiella spp. in I. ricinus accounts for adaptive selection in specific environments, while assessing potential co-phylogenetic associations between the symbiont and their tick hosts, as observed for other heritable endosymbionts [32, 68, 69].

Ticks are commonly co-infected with tick-borne pathogens, which have implications for public health [70]. The success of pathogen transmission, however, may be affected by their co-occurrence with symbiotic bacteria, leading to direct facilitation or competition effects among microbes [8]. Our results did not disclose any significant association between Rickettsiella symbionts and pathogens, which might entail that these symbionts do not interfere with the presence of B. burgdorferi s.l. and B. miyamotoi. These results are in line with previous studies in which a greater selection of tick-borne pathogens and symbionts was assessed [70]. By contrast, Aivelo et al. [35] reported strong associations between Rickettsiella spp. and different Lyme spirochetes. However, these positive correlations may be influenced by the greater proportion of adult ticks studied by Aivelo and colleagues, in which co-infections are more likely to occur compared to nymphs. Notwithstanding, our results do not exclude the possibility of associations between symbionts and pathogens. The heterogenicity of our results may not only be biased by differences in the epidemiological context, but also influenced by the diverse sample size tested per each geographic location.

\section{Conclusions}

Our study demonstrates the widespread distribution of Rickettsiella symbionts among I. ricinus populations in Europe. Overall, Rickettsiella spp. displayed a high genetic variability according to the geographic locations, which highlights the importance of small-scale factors in shaping the distribution of this symbiotic bacterium. The in-depth evaluation of micro and macroclimatic variables affecting the occurrence of Rickettsiella spp. among different tick populations, as well as further phylogenetic studies, will hopefully elucidate co-evolution patterns between Rickettsiella spp. and ixodid ticks, and the specific geographic distribution of Rickettsiella strains. Moreover, our preliminary data suggest that Rickettsiella symbionts may also be present in other Ixodes species in Europe, but further research is needed to improve the knowledge about the symbiont's ecology. 


\section{Appendix}

Table 5 Origin and composition of the Ixodes ricinus populations investigated

\begin{tabular}{|c|c|c|c|c|c|c|c|}
\hline Region & Location & Coordinates & Larvae tested & Nymphs tested & Adult tested & Males & Females \\
\hline \multirow[t]{9}{*}{ The Netherlands } & Amsterdamse Waterleiding Duinen & $52^{\circ} 20^{\prime} \mathrm{N} 4^{\circ} 33^{\prime} \mathrm{E}$ & 244 & 103 & 1 & 0 & 1 \\
\hline & Bergherbos & $51^{\circ} 55^{\prime} \mathrm{N} 6^{\circ} 14^{\prime \prime} \mathrm{E}$ & - & 51 & 5 & 2 & 3 \\
\hline & Buunderkamp & $52^{\circ} 00^{\prime} \mathrm{N} 5^{\circ} 44^{\prime} \mathrm{E}$ & 123 & 46 & 2 & 1 & 1 \\
\hline & Duin en Kruidberg & $52^{\circ} 26^{\prime} \mathrm{N} 4^{\circ} 36^{\prime} \mathrm{E}$ & - & 93 & 3 & 2 & 1 \\
\hline & Deelerwoud & $52^{\circ} 05^{\prime} \mathrm{N}^{\circ} 56^{\prime} \mathrm{E}$ & - & 56 & 8 & 3 & 5 \\
\hline & Herperduin & $51^{\circ} 45^{\prime} \mathrm{N}^{\circ} 36^{\prime} \mathrm{E}$ & - & 40 & 7 & 2 & 5 \\
\hline & Kremboong & $52^{\circ} 45^{\prime} \mathrm{N} 6^{\circ} 31^{\prime} \mathrm{E}$ & - & 76 & 12 & 10 & 2 \\
\hline & Stameren & $52^{\circ} 03^{\prime} \mathrm{N}^{\circ} 21^{\prime} \mathrm{E}$ & - & 45 & 3 & 1 & 2 \\
\hline & Zwanemeerbos & $53^{\circ} 00^{\prime} \mathrm{N} 6^{\circ} 45^{\prime} \mathrm{E}$ & - & 78 & 2 & 1 & 1 \\
\hline \multirow[t]{3}{*}{ Italy } & Alpi Cozie Natural Park & $45^{\circ} 03^{\prime} \mathrm{N}^{\circ} 54^{\prime} \mathrm{E}$ & - & 785 & 0 & 0 & 0 \\
\hline & Aosta Valley & $45^{\circ} 47^{\prime} \mathrm{N} 7^{\circ} 19^{\prime} \mathrm{E}$ & - & 257 & 39 & 22 & 17 \\
\hline & Tuscany & $44^{\circ} 12^{\prime} \mathrm{N} 10^{\circ} 22^{\prime} \mathrm{E}$ & - & 284 & 3 & 3 & 0 \\
\hline Germany & Güterfelde & $52^{\circ} 21^{\prime} \mathrm{N} 13^{\circ} 11^{\prime} \mathrm{E}$ & - & 66 & 0 & 0 & 0 \\
\hline \multirow[t]{2}{*}{ UK } & Salisbury & $50^{\circ} 59^{\prime} \mathrm{N} 1^{\circ} 45^{\prime} \mathrm{W}$ & - & 111 & 9 & 0 & 9 \\
\hline & Dartmoor & $50^{\circ} 34^{\prime} \mathrm{N} 3^{\circ} 55^{\prime} \mathrm{W}$ & - & 107 & 13 & 0 & 13 \\
\hline Sweden & Södermanlands & $59^{\circ} 00^{\prime} \mathrm{N} 16^{\circ} 52^{\prime} \mathrm{E}$ & - & 216 & 19 & 9 & 10 \\
\hline Belgium & Antwerp & $51^{\circ} 16^{\prime} \mathrm{N}, 4^{\circ} 23^{\prime} \mathrm{E}$ & - & 1771 & 262 & 136 & 126 \\
\hline
\end{tabular}

Note: "-" indicates no specimens were tested for the corresponding tick life stage category

Supplementary Information The online version contains supplementary material available at https://doi.org/10.1007/s00248-021-01869-7.

Acknowledgements We would like to thank Ilary Millet and Alessandro Mannelli (University of Turin), Charlotte Ragagli (Ufficio Territoriale Carabinieri per la Biodiversità, Lucca), Elisa Ramassa and Massimo Rosso (Ente di gestione delle aree protette delle Alpi Cozie, Salbertrand, Turin), Ruth van den Herik (Wageningen University) and Nina Militzer (Freie Universität Berlin) for providing ticks/helping in tick collection in Italy, the Netherlands and Germany, and Ryanne Jaarsma for helping with lab work.

Author Contribution AIK, AG-V, and HS conceived and coordinated the project. HS acquired the funding. AG-V and LT performed data analyses and wrote the manuscript. LB assisted with performing data analyses. MF designed and set up protocols of the molecular study. AG-V, AIK, MF conducted the molecular analyses. AG-V, LT, AIK, $\mathrm{DH}, \mathrm{NDF}, \mathrm{JMM}, \mathrm{KMH}$, and AMN provided tick samples investigated. All authors revised and accepted the final version of the manuscript.

Funding Open access funding provided by Università degli Studi di Torino within the CRUI-CARE Agreement. This research was financially supported by the Dutch Ministry of Health, Welfare and Sport (VWS) and a grant from the European Interreg North Sea Region program, as part of the NorthTick project. AMN received financial support from the Federal Ministry of Education and Research (BMBF) under project number 01KI1720 as part of the 'Research Network Zoonotic
Infectious Diseases'. DH is funded by the Marie Sklodowska-Curie Actions (EU-Horizon 2020, Individual Global Fellowship, project no 799609).

Data Availability Representative sequence data are available on NCBI with Accession numbers: MW876489-MW876509.

\section{Declarations}

Ethics Approval and Consent to Participate Informed consent was obtained from all individual participants included in the study.

Conflict of Interest The authors declare no competing interests.

Open Access This article is licensed under a Creative Commons Attribution 4.0 International License, which permits use, sharing, adaptation, distribution and reproduction in any medium or format, as long as you give appropriate credit to the original author(s) and the source, provide a link to the Creative Commons licence, and indicate if changes were made. The images or other third party material in this article are included in the article's Creative Commons licence, unless indicated otherwise in a credit line to the material. If material is not included in the article's Creative Commons licence and your intended use is not permitted by statutory regulation or exceeds the permitted use, you will need to obtain permission directly from the copyright holder. To view a copy of this licence, visit http://creativecommons.org/licenses/by/4.0/. 


\section{References}

1. Tack W, Madde M, Baeten L, Vanhellemont M, Gruwez R, Verheyen K (2012) Local habitat and landscape affect Ixodes ricinus tick abundances in forests on poor, sandy soils. Forest Ecol Manag 265:30-36. https://doi.org/10.1016/j.foreco.2011.10.028

2. Estrada-Peña A, de la Fuente J (2014) The ecology of ticks and epidemiology of tick-borne viral diseases. Antiviral Res 108:104 128. https://doi.org/10.1016/j.antiviral.2014.05.016

3. Pollet T, Sprong H, Lejal E, Krawczyk AI, Moutailler S, Cosson JF, Vayssier-Taussat M, Estrada-Peña A (2020) The scale affects our view on the identification and distribution of microbial communities in ticks. Parasit Vectors 13:36. https://doi.org/10.1186/ s13071-020-3908-7

4. de la Fuente J, Estrada- Pena A, Venzal JM, Kocan KM, Sonenshine DE (2008) Overview: ticks as vectors of pathogens that cause disease in humans and animals. Front Biosci 13:6938-6946. https://doi.org/10.2741/3200

5. Heyman P, Cochez C, Hofhuis A, van der Giessen J, Sprong H, Porter SR, Losson B, Saegerman C, Donoso-Mantke O, Niedrig M, Papa A (2010) A clear and present danger: tick-borne diseases in Europe. Expert Rev Anti Infect Ther 8:33-50. https://doi.org/ 10.1586/eri.09.118

6. Dantas-Torres F, Chomel BB, Otranto D (2012) Ticks and tickborne diseases: a one health perspective. Trends Parasitol 28:437446. https://doi.org/10.1016/j.pt.2012.07.003

7. Rizzoli A, Silaghi C, Obiegala A, Rudolf I, Hubálek Z, Földvári $\mathrm{G}$, Plantard $\mathrm{O}$, Vayssier-Taussat $\mathrm{M}$, Bonnet $\mathrm{S}$, Spitalská $\mathrm{E}$, Kazimírová M (2014) Ixodes ricinus and its transmitted pathogens in urban and peri-urban areas in Europe: new hazards and relevance for public health. Front Public Health 2:251. https://doi. org/10.3389/fpubh.2014.00251

8. Bonnet SI, Binetruy F, Hernández-Jarguín AM, Duron O (2017) The tick microbiome: why non-pathogenic microorganisms matter in tick biology and pathogen transmission. Front Cell Infect Microbiol 7:236. https://doi.org/10.3389/fcimb.2017.00236

9. Zhong J, Jasinskas A, Barbour AG (2007) Antibiotic treatment of the tick vector Amblyomma americanum reduced reproductive fitness. PLoS ONE 2:e405. https://doi.org/10.1371/journal.pone. 0000405

10. Guizzo MG, Parizi LF, Nunes RD, Schama R, Albano RM, Tirloni L, Oldiges DP, Vieira RP, Oliveira WHC, Leite MS, Gonzales SA, Farber M, Martins O, Vaz IDS Jr, Oliveira PL (2017) A Coxiella mutualist symbiont is essential to the development of Rhipicephalus microplus. Sci Rep 7:17554. https://doi.org/10. 1038/s41598-017-17309-x

11. Duron O, Morel O, Noël V, Buysse M, Binetruy F, Lancelot R, Loire E, Ménard C, Bouchez O, Vavre F, Vial L (2018) Tickbacteria mutualism depends on B vitamin synthesis pathways. Curr Biol 28:1896-1902.e5. https://doi.org/10.1016/j.cub.2018. 04.038

12. Hubálek Z (2009) Epidemiology of Lyme borreliosis. Curr Probl Dermatol 37:31-50. https://doi.org/10.1159/000213069

13. Cutler SJ, Vayssier-Taussat M, Estrada-Peña A, Potkonjak A, Mihalca AD, Zeller H (2019) A new Borrelia on the block: Borrelia miyamotoi-a human health risk? Euro Surveill 24:1800170. https://doi.org/10.2807/1560-7917.ES.2019.24.18.1800170

14. Beninati T, Lo N, Sacchi L, Genchi C, Noda H, Bandi C (2004) A novel alpha-Proteobacterium resides in the mitochondria of ovarian cells of the tick Ixodes ricinus. Appl Environ Microbiol 70:2596-2602. https://doi.org/10.1128/aem.70.5.2596-2602.2004

15. Sacchi L, Bigliardi E, Corona S, Beninati T, Lo N, Franceschi A (2004) A symbiont of the tick Ixodes ricinus invades and consumes mitochondria in a mode similar to that of the parasitic bacterium Bdellovibrio bacteriovorus. Tissue Cell 36:43-53. https://doi.org/10.1016/j.tice.2003.08.004

16. Olivieri E, Epis S, Castelli M, Varotto Boccazzi I, Romeo C, Desirò A, Bazzocchi C, Bandi C, Sassera D (2019) Tissue tropism and metabolic pathways of Midichloria mitochondrii suggest tissue-specific functions in the symbiosis with Ixodes ricinus. Ticks Tick Borne Dis 10:1070-1077. https://doi.org/ 10.1016/j.ttbdis.2019.05.019

17. Mariconti M, Epis S, Gaibani P, Dalla Valle C, Sassera D, Tomao P, Fabbi M, Castelli F, Marone P, Sambri V, Bazzocchi C, Bandi C (2012) Humans parasitized by the hard tick Ixodes ricinus are seropositive to Midichloria mitochondrii: is Midichloria a novel pathogen, or just a marker of tick bite? Pathog Glob Health 106:391-396. https://doi.org/10.1179/20477 73212 Y.0000000050

18. Kurtti TJ, Palmer AT, Oliver JH Jr (2002) Rickettsiella-like bacteria in Ixodes woodi (Acari: Ixodidae). J Med Entomol 39:534-540. https://doi.org/10.1603/0022-2585-39.3.534

19. Vilcins IM, Old JM, Deane E (2009) Molecular detection of Rickettsia, Coxiella and Rickettsiella DNA in three native Australian tick species. Exp Appl Acarol 49:229-242. https://doi.org/10. 1007/s10493-009-9260-4

20. Carpi G, Cagnacci F, Wittekindt NE, Zhao F, Qi J, Tomsho LP, Drautz DI, Rizzoli A, Schuster SC (2011) Metagenomic profile of the bacterial communities associated with Ixodes ricinus ticks. PLoS ONE 6:e25604. https://doi.org/10.1371/journal.pone.00256 04

21. Anstead CA, Chilton NB (2014) Discovery of novel Rickettsiella spp. in ixodid ticks from Western Canada. Appl Environ Microbiol 80:1403-1410. https://doi.org/10.1128/AEM.03564-13

22. Duron O, Cremaschi J, McCoy KD (2016) The high diversity and global distribution of the intracellular bacterium Rickettsiella in the polar seabird tick Ixodes uriae. Microb Ecol 71:761-770. https://doi.org/10.1007/s00248-015-0702-8

23. Cordaux R, Paces-Fessy M, Raimond M, Michel-Salzat A, Zimmer M, Bouchon D (2007) Molecular characterization and evolution of arthropod-pathogenic Rickettsiella bacteria. Appl Environ Microbiol 73:5045-5047. https://doi.org/10.1128/aem.00378-07

24. Leclerque A, Kleespies RG (2008) 16S rRNA-, GroEL- and MucZbased assessment of the taxonomic position of 'Rickettsiella melolonthae' and its implications for the organization of the genus Rickettsiella. Int J Syst Evol Microbiol 58:749-755. https://doi. org/10.1099/ijs.0.65359-0

25. Leclerque A, Kleespies RG (2008) Type IV secretion system components as phylogenetic markers of entomopathogenic bacteria of the genus Rickettsiella. FEMS Microbiol Ecol 279:167-173. https://doi.org/10.1111/j.1574-6968.2007.01025.x

26. De Luna CJ, Moro CV, Guy JH, Zenner L, Sparagano OA (2009) Endosymbiotic bacteria living inside the poultry red mite (Dermanyssus gallinae). Exp Appl Acarol 48:105-113. https:// doi.org/10.1007/s10493-008-9230-2

27. Kleespies RG, Marshall SD, Schuster C, Townsend RJ, Jackson TA, Leclerque A (2011) Genetic and electron-microscopic characterization of Rickettsiella bacteria from the manuka beetle, Pyronota setosa (Coleoptera: Scarabaeidae). J Invertebr Pathol 107:206-211. https://doi.org/10.1016/j.jip.2011.05.017

28. Kleespies RG, Federici BA, Leclerque A (2014) Ultrastructural characterization and multilocus sequence analysis (MLSA) of 'Candidatus Rickettsiella isopodorum', a new lineage of intracellular bacteria infecting woodlice (Crustacea: Isopoda). Syst Appl Microbiol 37:351-359. https://doi.org/10.1016/j.syapm.2014.04. 001

29. Schuster C, Kleespies RG, Ritter C, Feiertag S, Leclerque A (2013) Multilocus sequence analysis (MLSA) of 'Rickettsiella agriotidis', an intracellular bacterial pathogen of Agriotes 
wireworms. Curr Microbiol 66:1-9. https://doi.org/10.1007/ s00284-012-0219-z

30. Rosenwald LC, Sitvarin MI, White JA (2020) Endosymbiotic Rickettsiella causes cytoplasmic incompatibility in a spider host. Proc Biol Sci 287:20201107. https://doi.org/10.1098/rspb.2020. 1107

31. Tsuchida T, Koga R, Horikawa M, Tsunoda T, Maoka T, Matsumoto S, Simon JC, Fukatsu T (2010) Symbiotic bacterium modifies aphid body color. Science 330:1102-1104. https://doi.org/10. 1126/science.1195463

32. Duron O, Noël V, McCoy KD, Bonazzi M, Sidi-Boumedine K, Morel O, Vavre F, Zenner L, Jourdain E, Durand P, Arnathau C, Renaud F, Trape JF, Biguezoton AS, Cremaschi J, Dietrich M, Léger E, Appelgren A, Dupraz M, Gómez-Díaz E, Diatta G, Dayo GK, Adakal H, Zoungrana S, Vial L, Chevillon C (2015) The recent evolution of a maternally-inherited endosymbiont of ticks led to the emergence of the $\mathrm{Q}$ fever pathogen Coxiella burnetii. PLoS Pathog 11:e1004892. https://doi.org/10.1371/journal.ppat. 1004892

33. Cerutti F, Modesto P, Rizzo F, Cravero A, Jurman I, Costa S, Giammarino M, Mandola ML, Goria M, Radovic S, Cattonaro F, Acutis PL, Peletto S (2018) The microbiota of hematophagous ectoparasites collected from migratory birds. PLoS ONE 13:e0202270. https://doi.org/10.1371/journal.pone.0202270

34. Estrada-Peña A, Cabezas-Cruz A, Pollet T, Vayssier-Taussat M, Cosson J-F (2018) High throughput sequencing and network analysis disentangle the microbial communities of ticks and hosts within and between ecosystems. Front Cell Infect Microbiol 8:236. https://doi.org/10.3389/fcimb.2018.0023

35. Aivelo T, Norberg A, Tschirren B (2019) Bacterial microbiota composition of Ixodes ricinus ticks: the role of environmental variation, tick characteristics and microbial interactions. PeerJ 7:e8217. https://doi.org/10.7717/peerj.8217

36. Estrada-Peña A, Mihalca AD, Petney TN (2017) Ticks of Europe and North Africa: a guide to species identification. Springer, Switzerland. https://doi.org/10.1007/978-3-319-63760-0

37. Heylen D, Lasters R, Adriaensen F, Fonville M, Sprong H, Matthysen E (2019) Ticks and tick-borne diseases in the city: Role of landscape connectivity and green space characteristics in a metropolitan area. Sci Total Environ 670:941-949. https://doi.org/10. 1016/j.scitotenv.2019.03.235

38. Ragagli C, Mannelli A, Ambrogi C, Bisanzio D, Ceballos LA, Grego E, Martello E, Selmi M, Tomassone L (2016) Presence of host-seeking Ixodes ricinus and their infection with Borrelia burgdorferi sensu lato in the Northern Apennines, Italy. Exp Appl Acarol 69:167-178. https://doi.org/10.1007/s10493-016-0030-9

39. Millet I, Ragionieri M, Tomassone L, Trentin C, Mannelli A (2019) Assessment of the exposure of people to questing ticks carrying agents of zoonoses in Aosta Valley. Italy Vet Sci 6:28. https://doi.org/10.3390/vetsci6010028

40. Garcia-Vozmediano A, Krawczyk AI, Sprong H, Rossi L, Ramassa E, Tomassone L (2020) Ticks climb the mountains: ixodid tick infestation and infection by tick-borne pathogens in Western Alps. Ticks Tick Borne Dis 11:101489. https://doi.org/10.1016/j.ttbdis. 2020.101489

41. Wielinga PR, Gaasenbeek C, Fonville M, de Boer A, de Vries A, Dimmers W, Akkerhuis Op Jagers G, Schouls LM, Borgsteede F, van der Giessen JW (2006) Longitudinal analysis of tick densities and Borrelia, Anaplasma, and Ehrlichia infections of Ixodes ricinus ticks in different habitat areas in The Netherlands. Appl Environ Microbiol 72:7594-7601. https://doi.org/10.1128/aem. 01851-06

42. Heylen D, Tijsse E, Fonville M, Matthysen E, Sprong H (2013) Transmission dynamics of Borrelia burgdorferi s.l. in a bird tick community. Environ Microbiol 15:663-673. https://doi.org/10. $1111 / 1462-2920.12059$
43. Hovius JW, de Wever B, Sohne M, Brouwer MC, Coumou J, Wagemakers A, Oei A, Knol H, Narasimhan S, Hodiamont CJ, Jahfari S, Pals ST, Horlings HM, Fikrig E, Sprong H, van Oers MH (2013) A case of meningoencephalitis by the relapsing fever spirochaete Borrelia miyamotoi in Europe. Lancet 382:658. https://doi.org/10.1016/S0140-6736(13)61644-X

44. Leclerque A, Kleespies RG, Schuster C, Richards NK, Marshall SD, Jackson TA (2012) Multilocus sequence analysis (MLSA) of 'Rickettsiella costelytrae' and 'Rickettsiella pyronotae', intracellular bacterial entomopathogens from New Zealand. J Appl Microbiol 113:1228-1237

45. RStudio Team (2020). RStudio: integrated development for R. RStudio, PBC, Boston, MA. http://www.rstudio.com/

46. Fleiss JL (1981) Statistical methods for rates and proportions. J Wiley, New York

47. Thompson JD, Higgins DG, Gibson TJ (1994) CLUSTAL W: improving the sensitivity of progressive multiple sequence alignment through sequence weighting, positions-specific gap penalties and weight matrix choice. Nucleic Acids Res 22:4673-4680. https://doi.org/10.1093/nar/22.22.4673

48. Abascal F, Zardoya R, Telford MJ (2010) TranslatorX: multiple alignment of nucleotide sequences guided by amino acid translations. Nucleic Acids Res 38:W7-13. https://doi.org/10.1093/nar/ gkq291

49. Tavaré S (1986) Some probabilistic and statistical problems in the analysis of DNA sequences. Lectures on Mathematics in the Life Sciences 17:57-86

50. Ronquist F, Teslenko M, van der Mark P, Ayres DL, Darling A, Höhna S, Larget B, Liu L, Suchard MA, Huelsenbeck JP (2012) MRBAYES 3.2: efficient Bayesian phylogenetic inference and model selection across a large model space. Syst Biol 61:539-542. https://doi.org/10.1093/sysbio/sys029

51. Drummond AJ, Suchard MA, Xie D, Rambaut A (2012) Bayesian phylogenetics with BEAUti and the BEAST 1.7. Mol Biol Evol 29:1969-1973. https://doi.org/10.1093/molbev/mss075

52. Kueneman JG, Esser HJ, Weiss SJ, Jansen PA, Foley JE (2021) Tick microbiomes in neotropical forest fragments are best explained by tick-associated and environmental factors rather than host blood source. Appl Environ Microbiol 87:e02668-e2720. https://doi.org/10.1128/AEM.02668-20

53. Sakamoto JM, Silva Diaz GE, Wagner EA (2020) Bacterial communities of Ixodes scapularis from central Pennsylvania, USA. Insects 11:718. https://doi.org/10.3390/insects11100718

54. Duron O, Binetruy F, Noël V, Cremaschi J, McCoy KD, Arnathau C, Plantard O, Goolsby J, Pérez de León AA, Heylen DJA, Van Oosten AR, Gottlieb Y, Baneth G, Guglielmone AA, Estrada-Peña A, Opara MN, Zenner L, Vavre F, Chevillon C (2017) Evolutionary changes in symbiont community structure in ticks. Mol Ecol 26:2905-2921. https://doi.org/10.1111/mec.14094

55. Van Oosten AR, Duron O, Heylen DJA (2018) Sex ratios of the tick Ixodes arboricola are strongly female-biased, but there are no indications of sex-distorting bacteria. Ticks Tick Borne Dis 9:307-313. https://doi.org/10.1016/j.ttbdis.2017.11.004

56. Lindquist EE, Galloway TD, Artsob H, Lindsay LR, Drebot M, Wood H, Robbins RG (2016) A handbook to the ticks of Canada (Ixodida: Ixodidae, Argasidae). Biological Survey of Canada Monograph Series No. 7, Ottawa. https://doi.org/10.3752/97809 68932186

57. Cringoli G, Iori A, Rinaldi L, Veneziano V, Genchi C (2005) Zecche. Ronaldo Editore, Napoli, Italy.

58. Zolnik CP, Falco RC, Daniels TJ, Kolokotronis SO (2018) Transient influence of blood meal and natural environment on blacklegged tick bacterial communities. Ticks Tick Borne Dis 9:563-572. https://doi.org/10.1016/j.ttbdis.2018.01.007

59. Zolnik CP, Prill RJ, Falco RC, Daniels TJ, Kolokotronis SO (2016) Microbiome changes through ontogeny of a tick pathogen 
vector. Mol Ecol 25:4963-4977. https://doi.org/10.1111/mec. 13832

60. Rynkiewicz EC, Hemmerich C, Rusch DB, Fuqua C, Clay K (2015) Concordance of bacterial communities of two tick species and blood of their shared rodent host. Mol Ecol 24:2566-2579. https://doi.org/10.1111/mec.13187

61. Swei A, Kwan J (2017) Tick microbiome and pathogen acquisition altered by host blood meal. ISME J 11:813-816. https://doi.org/ 10.1038/ismej.2016.152

62. Leclerque A, Hartelt K, Schuster C, Jung K, Kleespies RG (2011) Multilocus sequence typing (MLST) for the infra-generic taxonomic classification of entomopathogenic Rickettsiella bacteria. FEMS Microbiol Lett 324:125-134. https://doi.org/10.1111/j. 1574-6968.2011.02396.x

63. Tsuchida T, Koga R, Fujiwara A, Fukatsu T (2014) Phenotypic effect of "Candidatus Rickettsiella viridis," a facultative symbiont of the pea aphid (Acyrthosiphon pisum), and its interaction with a coexisting symbiont. Appl Environ Microbiol 80:525-533. https:// doi.org/10.1128/aem.03049-13

64. Iasur-Kruh L, Weintraub PG, Mozes-Daube N, Robinson WE, Perlman SJ, Zchori-Fein E (2013) Novel Rickettsiella bacterium in the leafhopper Orosius albicinctus (Hemiptera: Cicadellidae). Appl Environ Microbiol 79:4246-4252. https://doi.org/10.1128/ aem.00721-13

65. Łukasik P, Dawid MA, Ferrari J, Godfray HC (2013) The diversity and fitness effects of infection with facultative endosymbionts in the grain aphid, Sitobion avenae. Oecologia 173:985-996. https:// doi.org/10.1007/s00442-013-2660-5
66. Mediannikov O, Sekeyová Z, Birg ML, Raoult D (2010) A novel obligate intracellular gamma-proteobacterium associated with ixodid ticks, Diplorickettsia massiliensis, Gen. Nov., Sp. Nov. PLoS One 5:e11478. https://doi.org/10.1371/journal.pone.0011478

67. Leclerque A, Kleespies RG (2012) A Rickettsiella bacterium from the hard tick, Ixodes woodi: molecular taxonomy combining multilocus sequence typing (MLST) with significance testing. PLoS ONE 7:e38062. https://doi.org/10.1371/journal.pone.0038062

68. Al-Khafaji AM, Clegg SR, Pinder AC, Luu L, Hansford KM, Seelig F, Dinnis RE, Margos G, Medlock JM, Feil EJ, Darby AC, McGarry JW, Gilbert L, Plantard O, Sassera D, Makepeace BL (2019) Multi-locus sequence typing of Ixodes ricinus and its symbiont Candidatus Midichloria mitochondrii across Europe reveals evidence of local co-cladogenesis in Scotland. Ticks Tick Borne Dis 10:52-62. https://doi.org/10.1016/j.ttbdis.2018.08.016

69. Coimbra-Dores MJ, Jaarsma RI, Carmo AO, Maia-Silva M, Fonville M, da Costa DFF, Brandão RML, Azevedo F, Casero M, Oliveira AC, Afonso SMS, Sprong H, Rosa F, Dias D (2020) Mitochondrial sequences of Rhipicephalus and Coxiella endosymbiont reveal evidence of lineages co-cladogenesis. FEMS Microbiol Ecol 96:fiaa072. https://doi.org/10.1093/femsec/fiaa072

70. Moutailler S, Valiente Moro C, Vaumourin E, Michelet L, Tran FH, Devillers E, Cosson JF, Gasqui P, Van VT, Mavingui P, Vourc'h G, Vayssier-Taussat M (2016) Co-infection of ticks: the rule rather than the exception. PLoS Negl Trop Dis 10:e004539. https://doi.org/10.1371/journal.pntd.0004539

\section{Authors and Affiliations}

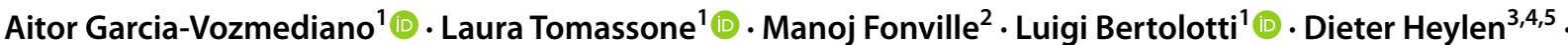 Nannet D. Fabri, ${ }^{6,7}$ Jolyon M. Medlock ${ }^{8} \cdot$ Ard M. Nijhof $^{9}$ (1) $\cdot$ Kayleigh M. Hansford ${ }^{8} \cdot$ Hein Sprong ${ }^{2}$ (1) . Aleksandra I. Krawczyk ${ }^{2,10}$ (D)}

\author{
Laura Tomassone \\ laura.tomassone@unito.it \\ Manoj Fonville \\ manoj.fonville@rivm.nl \\ Luigi Bertolotti \\ luigi.bertolotti@unito.it \\ Dieter Heylen \\ dheylen@itg.be \\ Nannet D. Fabri \\ nannet.fabri@slu.se \\ Jolyon M. Medlock \\ jolyon.medlock@phe.gov.uk \\ Ard M. Nijhof \\ Ard.Nijhof@fu-berlin.de
}

Kayleigh M. Hansford

Kayleigh.Hansford@phe.gov.uk

Hein Sprong

hein.sprong@rivm.nl

1 Department of Veterinary Sciences, University of Turin, L.go Braccini, 2, 10095 Grugliasco, TO, Italy
2 Centre for Infectious Disease Control, National Institute for Public Health and the Environment (RIVM), Antonie van Leeuwenhoeklaan 9, 3720 BA Bilthoven, The Netherlands

3 Eco-Epidemiology Group, Department of Biomedical Sciences, Institute of Tropical Medicine, Antwerp, Belgium

4 Evolutionary Ecology Group, Department of Biology, University of Antwerp, Wilrijk, Belgium

5 Interuniversity Institute for Biostatistics and Statistical Bioinformatics, Hasselt University, Diepenbeek, Belgium

6 Department of Wildlife, Fish, and Environmental Studies, Swedish University of Agricultural Sciences, 90183 Umeå, Sweden

7 Department of Population Health Sciences, Faculty of Veterinary Medicine, Utrecht University, Yalelaan 7. 3584 CL Utrecht, The Netherlands

8 Infections Medical Entomology \& Zoonoses Ecology, Public Health England, Porton Down, UK

9 Institute for Parasitology and Tropical Veterinary Medicine, Freie Universität Berlin, Robert-von-Ostertag-Str. 7-13, 14163 Berlin, Germany

10 Laboratory of Entomology, Wageningen University and Research Centre, Wageningen, The Netherlands 